\title{
Ismétlődő súlyos hypoglykaemiákhoz vezető neuropathia pancreatogen diabeteses betegben (esetismertetés)
}

Nyiraty Szabolcs dr., ${ }^{(1)}$ Fehértemplomi Katalin dr., ${ }^{(1)}$ Orosz Andrea dr., ${ }^{(2)}$ Lengyel Csaba dr., ${ }^{(1)}$ Ábrahám György dr., ${ }^{(1)}$ Kempler Péter dr., ${ }^{(3)}$ Várkonyi Tamás dr. ${ }^{(1)}$

\section{Osszefoglalắs}

A szerzök ismertetik a szénhidrátanyagcsere-variabilitás fogalmát és annak hátrányos következményeit, amelyek közül kiemelik az ismétlödö hypoglykaemiák kockázatának növekedését. Részletesen foglalkoznak azokkal a kóroktani tényezökkel, amelyek magyarázzák az autonóm neuropathia szerepét a súlyos hypoglykaemia kialakulásában. Elemzik a gyomorürülés lassulásának és a pancreas exokrin funkciójának szerepét a kóros vércukoresés létrejöttében. Esetismertetésük során bemutatják egy visszatéröen súlyos hypoglykemiákat elszenvedö pancreatogen diabeteses beteg esetén végzendö diagnosztikus tevékenységet és a terápiás lehetöségeket. A beteg adataiból és a kórkép követésének tapasztalataiból általános érvényü összefoglaló következetéseket vonnak le a pancreatogen diabetesben megfigyelhetö, súlyos neuropathia és felszivódási zavar miatt kialakuló hypoglykaemia ismérveiröl.

Kulcsszavak: hypoglykaemia, autonóm neuropathia, gastroparesis, pancreatogen diabetes

\section{Recurrent hypoglycemias caused by neuropathy in a patient with pancreatogenic diabetes. A case report}

Summary: The authors define the meaning of glycemic variability and the possible detrimental consequences including the increased risk of recurrent hypoglycemias. They describe the details of the role of autonomic neuropathy in the pathogenesis of severe hypoglycemia. Slower gastric emptying and impaired exocrine function are analyzed as pathogenetic factors of abnormally low glucose values. A case history demonstrates the diagnostic steps and therapeutic options of a patient with pancreatogenic diabetes and recurrent hypoglycemias. Rewieving the patient's data and the details of follow-up they draw general conclusions about the characteristics of the hypoglycemia detected in pancreatogenic diabetes associated with autonomic neuropathy and impaired intestinal absorption.

- Keywords: hypoglycaemia, autonomic neuropathy, gastroparesis, pancreatogenic diabetes

\section{Rövidítések}

BMI: testtömegindex (body mass index); CGM: folyamatos szövetiglukóz-monitorozás (continuous glucose monitoring); CT: komputertomográfia (computer tomography); EEG: elektroenkefalogram (electroencephalogram); Y-GT: gamma-glutamil-transzferáz (gamma glutamyltransferase); GFR: glomeruláris filtrációs ráta (glomerular filtration rate); NPH: neutral protamin Hagedorn; $\mathbf{T}_{1 / 2}$ : gyomorürülés felezési ideje (half time of gastric emptying)

$\mathrm{A}$ diabeteses betegek kezelése során az egyik legfontosabb feladat a szénhidrát-anyagcsere ingadozásmentes beállítása. Az ese- tek egy részében azonban az óhajtott egyensúly számos terápiaváltoztatás ellenére is elérhetetlennek bizonyul. Az utóbbi évek kóroktani, diagnosz- 
tikai és terápiás ismereteinek bővülése reményt jelenthet a hosszú ideje ingadozó anyagcseréjü betegek számára. Az instabil szénhidrátháztartást leginkább a glykaemiás variabilitás fogalmával jellemzik, ami a vércukorszint ingadozásának mértékét, az átlagos vércukortól való eltérését fejezi ki. ${ }^{1}$ A béta-sejt-funkció romlása a variabilitással szorosan összefügg mind 1-es, mind 2-es típusú diabetesben, a C-peptid-szint, valamint a variabilitás közötti inverz korreláció pedig a diabetes típusától függetlenül bizonyított. ${ }^{2,3}$ A szélsőségesen ingadozó anyagcsere mielőbbi felismerése és befolyásolása azért szükséges, mert összefüggésbe hozható a micro- és macrovascularis szövődmények kialakulásával, ${ }^{4}$ a többféle okból bekövetkező mortalitás gyakoriságának növekedésével, ${ }^{5}$ az oxidatív stressz fokozódásával ${ }^{6}$ és előre jelezheti a hypoglykaemia kockázatát. ${ }^{7}$ A hypoglykaemia gyakoriságát és a fekvőbeteg-osztályok emiatti terhelését jól dokumentálják azok az adatok, amelyek szerint az Egyesült Államokban ez a diagnózis a sürgősségi kórházi felvételek egyik fő oka a 65 év feletti korosztályban, ${ }^{8}$ és 10 év alatt a hypoglykaemia miatti osztályos ellátás száma 39\%-kal nőtt Angliában. ${ }^{9}$ A súlyos, eszméletvesztést okozó hypoglykaemia sürgősségi ellátást igénylő következményei mellett rövid és hosszú távon érvényesülő cardiovascularis kockázattal is számolni kell. Számos olyan kórélettani tényező hatása fokozódik miatta, amely az artheriosclerosis kialakulásához vagy progressziójához vezet, köztük a szimpatikus idegrendszer aktiválása, az endotheldiszfunkció növekedése, a gyulladásos folyamatok elősegítése, az oxidatív stressz létrejötte és a thrombosis-készséget fokozó thrombocytaaktiváció. ${ }^{10}$ Diabetesben a hirtelen szívhalál egyik fontos etiológiai tényezője a fokozott aritmia-hajlam, amit részben a hypoglykaemia okoz. ${ }^{11}$

A kognitív funkció zavara is sokkal gyakoribb azokban a személyekben, akik ismétlődő hypoglykaemiát szenvednek el; az irodalom azonban megosztott abban a vonatkozásban, hogy a hypoglykaemia okozza-e a mentális hanyatlást, vagy inkább a kóros vércukoresés a kognitív diszfunkció miatti hiányos compliance következtében alakul ki. ${ }^{12}$

A hypoglykaemia és annak veszélyes következményeinek létrejöttében az autonóm neuropathia több okból is jelentős szerepet játszik. A cardiovascularis adaptáció autonóm neuropathiában be- következő gyengülése a baroreflex-szenzitivitás csökkenésében és a szívfrekvencia-variabilitás beszűkülésében nyilvánul meg, és tovább fokozza a malignus ritmuszavarok hypoglykaemiában megfigyelt kockázatát. ${ }^{13} \mathrm{Az}$ autonóm neuropathia mellett fellépő súlyos hypoglykaemiák gyakoriságának növekedését részben az ellenregulációs mechanizmusok gyengülése magyarázza, amit a hypoglykaemia ingerére bekövetkező, a fiziológiáshoz képest csökkent reaktív peptid-, illetve hormonszintek igazolnak. ${ }^{14} \mathrm{Az}$ autonóm neuropathia miatti magas hypoglykaemia-kockázat további oka a hypoglykaemia-érzet kiesése, amely miatt a korai figyelmeztető jelek e betegekben hiányoznak és a hypoglykaemia súlyos neuroglykopeniás tünetek formájában manifesztálódik. A fenti jelenséget a szimpatoadrenális rendszer említett funkciózavara mellett a hypoglykaemia károsodott központi idegrendszeri észlelése, illetve az erre adott válaszreakciók idegrendszeri inkoordináltsága magyarázhatja. ${ }^{15} \mathrm{Az}$ autonóm neuropathia az emésztőtraktus müködését rontva szintén okozhat hypoglykaemiát, mivel a neuropathia által érintett motoros, szenzoros és szekretoros gastrointesztinális funkciók mind szerepet játszanak a vércukorérték szabályozásában. ${ }^{16}$ A gyomor ürülése zavarttá válik, ha a paraszimpatikus-szimpatikus idegrendszer közötti egyensúly az autonóm neuropathia miatt felborul. Mivel a paraszimpatikus funkció általában hamarabb károsodik, mint a szimpatikus, így a paraszimpatikus serkentő hatás alulmarad a szimpatikus gátló hatással szemben. ${ }^{17}$ A hypoglykaemia kialakulását röviden az a jelenség magyarázza, hogy ha étkezés előtt a beteg inzulint vagy hypoglykaemizáló orális antidiabetikumot alkalmaz, de az étkezés alatt és után a gyomor nem ürül kellő dinamikával, akkor a duodenumba nem jut időben szénhidrát, és így a vércukorcsökkentő hatás hamarabb érvényesül, mint az étkezés miatti vércukoremelkedés. A következő fázisban pedig hyperglykaemia alakul ki, amikor a szénhidrát kései felszívódása a lassult gyomor miatt a vércukorcsökkentő hatás lezajlása után következik be. A gyomorürülés zavarának diabetesben megfigyelt jellegzetessége, hogy a motilitás igazolt romlása ellenére is a betegek egy része panaszmentes marad, vagy csak enyhe dyspepsiás tüneteket említ. Sokszor csak súlyos gastroparesisben lép fel a hányinger, illetve az étkezést követő hányás. A 
fentiek miatt tehát csupán a panaszok és tünetek alapján az autonóm neuropathia okozta gyomorürülési zavar súlyossága nem becsülhető meg. ${ }^{18}$

A stabil anyagcseréhez a pancreas endokrin és exokrin állományának szoros együttműködése szükséges. Az utóbbi években igazolták, hogy 2-es típusú diabetesben, rossz anyagcsere-állapot esetén a pancreas exokrin funkciója csökkent. ${ }^{19} \mathrm{~A}$ szénhidrátanyagcsere ingadozásához és a hypoglykaemia-kockázat növekedéséhez vezethet a pancreatogen diabetesben észlelt exokrin elégtelenség is. ${ }^{20}$ Pancreatogen diabeteshez az akut és krónikus pancreatitis, a pancreascarcinoma, a hasnyálmirigy-eltávolítás utáni állapot és a cisztás fibrosis vezet. Az elégtelen pancreasenzim-elválasztás miatt az összetett szénhidrátok lebontása zavart szenved, és az emiatt létrejövő felszívódási zavar hypoglykaemiát okoz. Az alfa-sejtek károsodása okozta hiányzó glukagonhatás a hypoglykaemiával kapcsolatos ellenreguláció károsodását hozza létre, amihez sok esetben - leginkább alkoholistákban - hozzájárul az együttesen előforduló májérintettség miatti csökkent glukoneogenezis. ${ }^{21}$ A kifejezett glukózvariabilitás és a rejtett, tünetszegényen vagy atípusos tünetekkel zajló hypoglykaemiás epizódok kimutatása a gyakori vércukorönellenőrzés mellett a folyamatos szövetiglukóz-monitorozás (continuous glucose monitoring: CGM) módszerével végezhető. A $\mathrm{HbA}_{1 \mathrm{c}}$ az időben átlagolva mutatja az anyagcsere-állapotot, így nem ad felvilágosítást arról, hogy az egész napos vagy napok közötti glukózingadozás milyen mértékű volt. ${ }^{22} \mathrm{~A}$ hypoglykaemiás epizódok hátterében fennálló autonóm neuropathia elsősorban a cardiovascularis funkciók tanulmányozásával vagy manőverek végzésével vizsgálható, melyek közé a szívfrekvenvia-variabilitás, a baroreflex-szenzitivitás és a cardiovascularis reflexek tartoznak. A hypoglykaemia okaként szóba jövő gastroparesis gyanúja esetén a gyomor ürülésének pontos megjelenítésére a nemzetközi és hazai szakirodalom egyaránt az izotópos gyomorürülésvizsgálatot tartja arany standardnak. ${ }^{16}$

\section{Esetismertetés}

Az esetismertetésben szereplő 45 éves diabeteses férfi beteg egy otthonában elszenvedett, tónusos végtaggörccsel kísért, eszméletvesztéssel járó roszszullét kapcsán került sürgősséggel a neurológiai klinikára. A felvételét megelőző időszakban egyre gyakrabban ismétlődtek a fenti rohamok, amelyek néhány percig tartottak. Aura vagy tenebrositas nem kísérte ezeket. Az egyértelmű központi idegrendszeri tünetek miatt epilepszia irányában kezdték meg kivizsgálását. Korábbi anamnézisében a krónikus alkoholizmus mellett évek óta fennálló idült hasnyálmirigy-gyulladás szerepelt. Egy alkalommal pseudocystával szövődött akut pancreatitise zajlott, ami miatt duodenummegtartásos hasnyálmirigyfej-reszekción esett át. A heveny gyulladáshoz társuló diabeteses ketoacidosis kapcsán derült fény cukorbetegségére, ami miatt napi négyszeri adagolású intenzív humáninzulin-kezelést indítottak, illetve pancreasenzim-szubsztitúciót rendeltek el. A terápiás beállítás után diabetológiai és gasztroenterológiai ellenőrzésen egyre ritkábban jelent meg, majd mintegy 9 évig nem járt szakorvosnál, gyógyszereit rendszeresen nem szedte. Felvételekor BMI-értéke 20,1-nek bizonyult. A funkcionális és képalkotó vizsgálatok (EEG, koponya-CT, carotis-vertebralis Doppler-ultrahang) neurológiai okok fennállását nem igazolták. Tekintettel arra, hogy a délelőttönként ismétlődően fellépő súlyos hypoglykaemiák a korábbi eszméletvesztések okaként szóba jöttek, illetve mivel további napszakokban pedig magas vércukrokat észleltek, kérték belgyógyászati klinikánkra való áthelyezését az anyagcsere stabilizálása céljából. Diabetológiai osztályunkra történő átvételekor alkalmankénti hasmenésen és az alsó végtagokra lokalizálódó disztális, szimmetrikus zsibbadásérzésen kívül egyéb panasza nem volt. Klasszikus hypoglykaemiás tünetek nem előzték meg a kórosan alacsony vércukor miatti eszméletvesztéseit. Fizikális státusából astheniás alkata, illetve a köldöktől balra, az inzulin beadásának helyén tapintható mobilis, subcutan csomó emelendő ki. Laboratóriumi eredményeiben magas $\mathrm{HbA}_{1 \mathrm{c}}(10,2 \%)$ és éhomi vénás vércukor $(33,4-11,5 \mathrm{mmol} / \mathrm{l}) \mathrm{mu}$ tatkozott emelkedett $\gamma$-GT (109 E/l) és mérsékelt fokú vashiányos anaemia mellett. Vesefunkciója kisfokban beszűkült volt (kreatinin: $130 \mu \mathrm{mol} / \mathrm{l}$, GFR: $50 \mathrm{ml} /$ perc/testfelület). Vércukorprofiljában szélsőséges ingadozást tapasztaltunk, reggeli után konzekvensen visszatérő hypoglykaemiás epizódokkal. További vizsgálatok során az echo- 
kardiográfia teleszisztolés mitrális prolapsust, a hasi szonográfia meszes pancreast igazolt. Gastroscopia során ételmaradékkal fedett nagygörbület, gastrooesophagealis reflux, varicositas oesophagei grade I. került leírásra. Szövettani vizsgálat boholyatrophia jeleit nem igazolta, így coeliakia kizárható volt. A diabetes microvascularis szövődményeinek irányában szemészeti vizsgálat történt, amely enyhe fokú háttér-retinopathiát igazolt.

\section{Kiegészítő vizsgálatok neuropathia irányában}

A felmerülő autonóm neuropathia gyanúja miatt elvégeztük a Ewing által leírt cardiovascularis reflexteszteket, ${ }^{23}$ amelyek súlyos fokú idegrendszeri érintettséget mutattak (1. táblázat). A szenzoros neuropathia mértékét a hüvelykujjon és a hallu- xon vizsgáltuk 3 különböző frekvenciájú elektromos inger közlésével a Neurometer diagnosztikus készülék felhasználásával. A perifériás szenzoros funkció nem bizonyult kórosnak, annak ellenére, hogy az autonóm idegrendszer súlyosan érintett volt. Bár emésztőszervi panasza nem volt, de az autonóm neuropathia tesztek eredménye és a hypoglykaemiák előfordulása miatt felmerült a lassult gyomorürülés lehetősége, így izotópos gyomorürülés-vizsgálatot végeztünk. A radiofarmakon idő-aktivitás görbe alapján számított felezési ideje $\left(T_{1 / 2}\right)$ extrém lassú gyomorürülést igazolt ( $\mathrm{T}_{1 / 2}: 487,6$ perc, normális tartomány: $\leq 67,6$ perc), ami magyarázatul szolgált az étkezések utáni súlyos vércukorcsökkenések kialakulására (2. táblázat). Tekintve a súlyos fokú autonóm idegrendszeri érintettséget, felmerült a hypoglykaemia-érzet

1. táblázat. Cardiovascularis reflexteszt vizsgálatok a beteg felvételekor és 6 hónappal később

\begin{tabular}{|c|c|c|c|}
\hline Teszt & Elsö ellátás & Kontrollvizsgálat & Normáltartomány \\
\hline Légzés alatti szivfrekvencia-változás & $4 /$ perc & $1 /$ perc & $\geq 15 /$ perc \\
\hline Valsalva-hányados & 1,015 & 1,025 & $\geq 1,21$ \\
\hline $30 / 15$ hányados & 1,012 & 1,005 & $\geq 1,04$ \\
\hline Ortosztatikus szisztolés vérnyomásesés & $16 \mathrm{Hgmm}$ & $38 \mathrm{Hgmm}$ & $\leq 10 \mathrm{Hgmm}$ \\
\hline Diasztolés vérnyomásemelkedés handgrip alatt & $7 \mathrm{Hgmm}$ & $1 \mathrm{Hgmm}$ & $\leq 16 \mathrm{Hgmm}$ \\
\hline Összesített score & $8 \mathrm{pont}$ & $9 \mathrm{pont}$ & $\leq 2$ pont \\
\hline
\end{tabular}

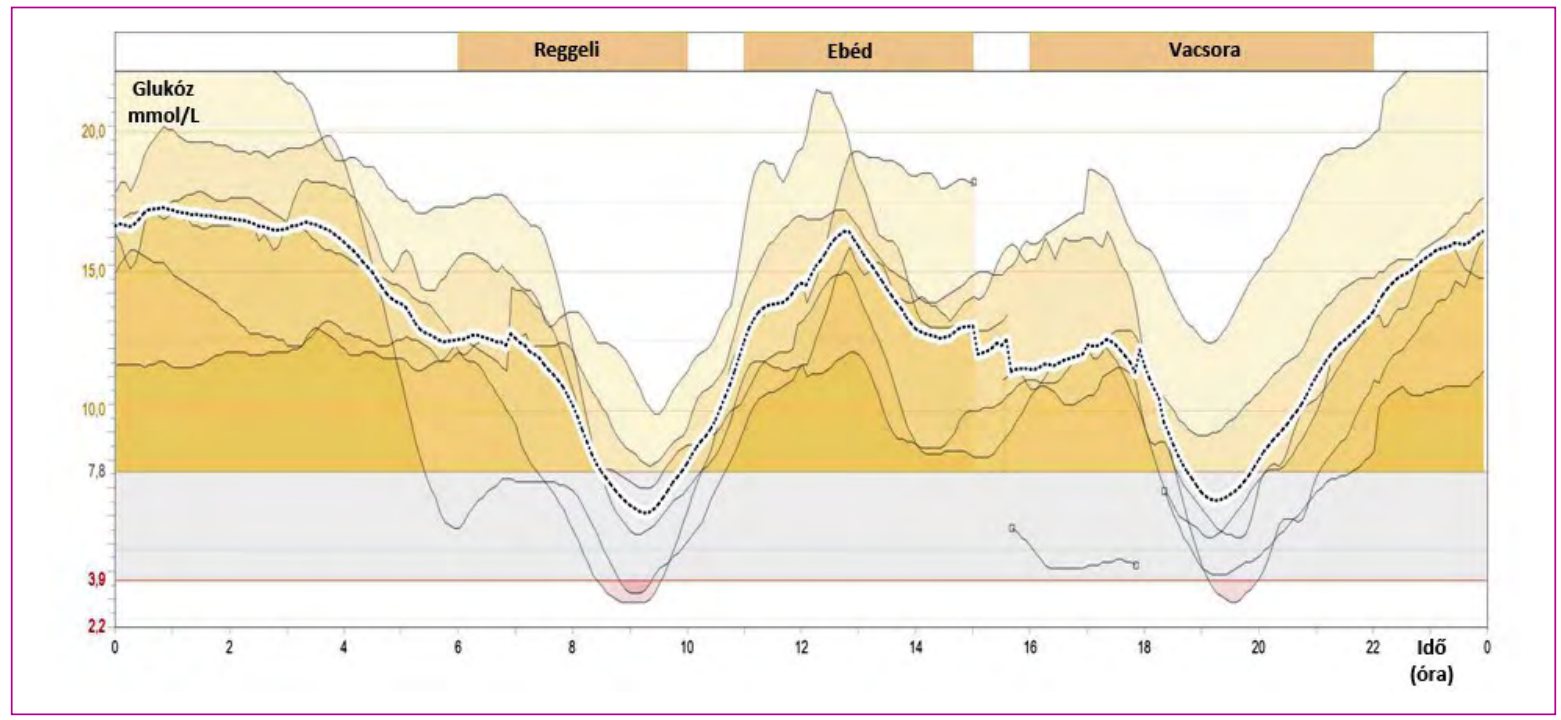

1. ábra. CGM a kezelés előtt 
kórosan csökkent mértéke is, ezért feltételezhető volt, hogy olyan hypoglykaemiás epizódokra is sor került, melyek tüneteit nem vagy atípusosan érezte a beteg. A rejtett hypoglykaemiák felderítésére és a napi vércukor-ingadozás jellemzőinek detektálására folyamatos szövetiglukóz-mérést (CGM-t) alkalmaztunk. A CGM elvégzésével konzekvensen reggeli és vacsora után jelentkező, jól reprodukálható glukózcsökkenés volt igazolható, ami magyarázatot adott a reggeli utáni eszméletvesztések etiológiájára (1. ábra). A vércukoreséseket a diabetológiában jól ismert Somogyi-effektus követte, aminek következtében a glukózértékek igen magas tartományba is kerültek.

\section{Alkalmazott kezelés, eredmények}

Az igazolt autonóm neuropathia miatt parenterálisian, majd per os naponta $600 \mathrm{mg}$ alfa-liponsavat alkalmaztunk, illetve a neurológián megkezdett gabapentinterápiát folytattunk. Az inzulinadagolás helyéről, technikájáról a beteget kiképeztük. A korábbi, négyszeri adagolású humáninzulin-kezelése során reggeli előtt $12 \mathrm{E}$, ebéd előtt $12 \mathrm{E}$, vacsora előtt $12 \mathrm{E}$ humán reguláris inzulint adagolt, lefekvéskor pedig 14 E NPH-inzulint injektált. A reggeli és esti postprandialis hypoglykaemia-kockázat miatt napi háromszori preprandialis, kis dózisú, ultragyors hatású inzulinanalógra (inzulin aspart) és napi kétszeri adagolású bázisinzulin-analógra (detemir) változtattuk kezelését. Napi inzulinadagja a felvételihez képest jóval kisebbnek bizonyult hazabocsátásakor (inzulin aspart reggeli előtt $6 \mathrm{E}$, ebéd előtt $6 \mathrm{E}$, vacsora előtt $8 \mathrm{E}$, inzulin detemir reggeli előtt $4 \mathrm{E}$, vacsora előtt $6 \mathrm{E}$ volt). A reggeli előtti ultragyors inzulinból idővel egyre kisebb adag volt csak szükséges, a délelőtti vércukoremelkedést pedig a reggel adagolt bázisinzulin-analóg dózisának feltitrálása mérsékelte. A lassult gyomorürülés miatt napi $3 \times 10 \mathrm{mg}$ vénás metoclopramid adását kezdtük meg. A korábban

\section{2. táblázat. A gyomorürülés izotópos vizsgálata a beteg felvételekor és 6 hónappal később}

\begin{tabular}{|c|c|c|c|}
\hline Paraméter & Első vizsgálat & Kontrollvizsgálat & Normáltartomány \\
\hline $\mathrm{T}_{1 / 2}$ (perc) & 487,6 & 245,8 & $\leq 67,6$ \\
\hline
\end{tabular}

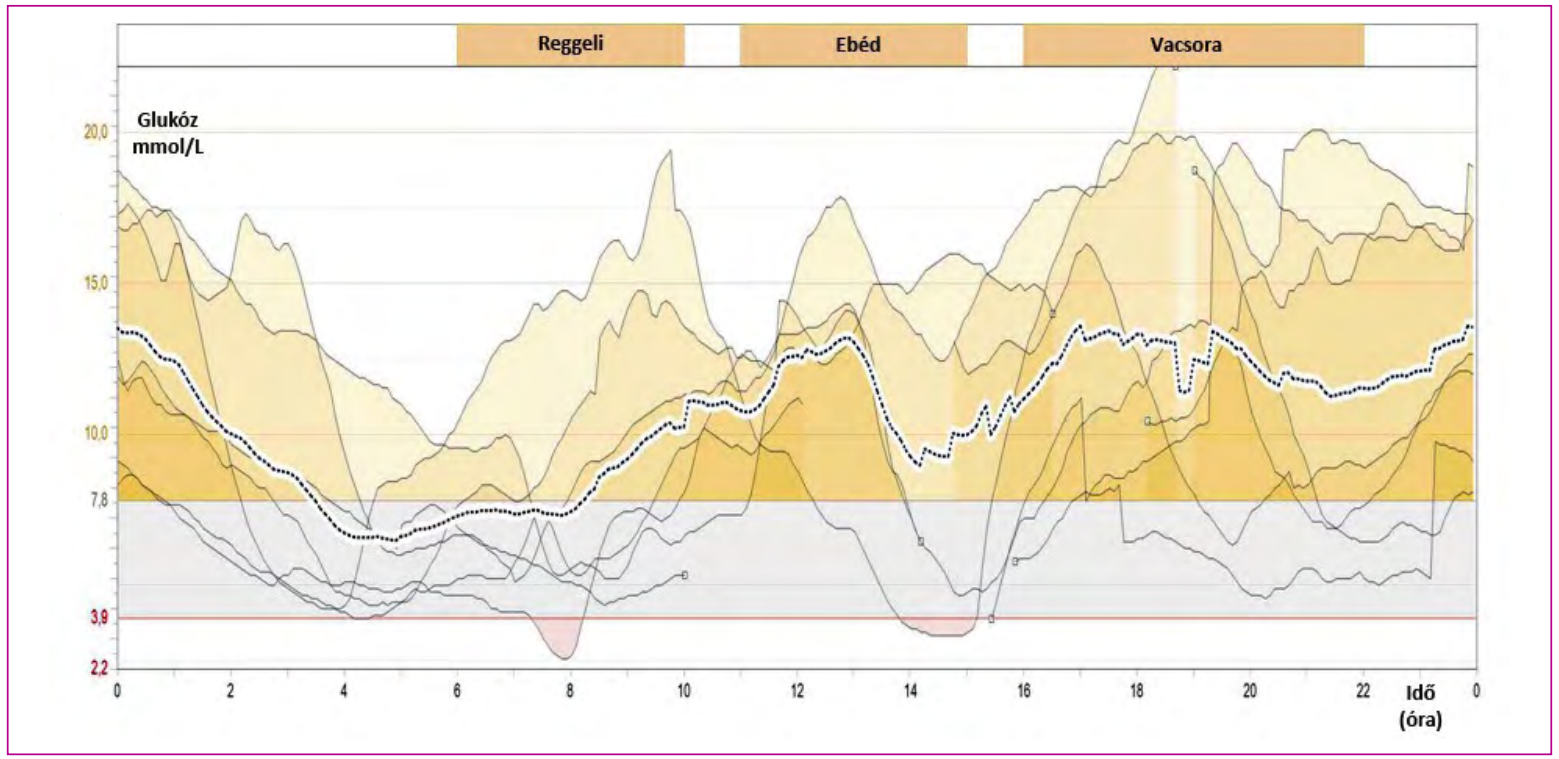

2. ábra. CGM a kezelés után 6 hónappal 
a beteg által elhagyott pancreasenzim-szubsztitúciót folytattuk, napi $4 \times 25000 \mathrm{E}$ pankreatint rendeltünk.

A beteg étrendjében rostszegény, naponta 6 alkalommal, egy-egy alkalommal kis mennyiségű ételt fogyasztott. A terápia eredményeként a hypoglykaemiák teljesen megszűntek, az anyagcsere stabilabbá vált. A beteg panasz- és tünetmentesen távozott osztályunkról. Utánkövetése során arról számolt be, hogy egyetlen hypoglykaemiás rosszullétre vagy eszméletvesztésre sem került sor, és életminőségének jelentős javulását említette. Otthon mért vércukorértékei között többségében a céltartományon belüli számadatok szerepeltek. A 6 hónapos kontrollvizsgálat idejében a $T_{1 / 2}$ megfeleződött, tehát mintegy kétszer olyan gyorsan ürült a beteg gyomra a terápiának köszönhetően, mint az első felvétel idején, de még mindig a kóros tartományban maradt (2. táblázat). $\mathrm{Az}$ autonóm neuropathia a kontrollvizsgálat idején még nem mutatott mérhető javulást a korábbiakhoz képest. A 6 hónapos kontroll során mért $\mathrm{HbA}_{1 \mathrm{c}}$ nem változott a kiindulási értékhez képest, és a kontroll-CGM-vizsgálat ingadozó vércukorértékeket igazolt ugyan, de a szélsőséges kilengések megszűntek és a postprandialis hypoglykaemia-hajlam is csökkent (2. ábra).

\section{Megbeszélés}

Az esetismertetésben szereplő beteg a konvulzív rosszullétei miatt sürgősséggel neurológiára került, mert tünetei nem feleltek meg a hypoglykaemia klasszikus klinikai képének. Nem voltak egyáltalán bevezető tünetek, és a hypoglykaemia-érzet neuropathia miatti kiesése, valamint az ellenregulációs védelmi mechanizmus elégtelensége miatt a hypoglykaemia első jele az eszméletvesztés volt. A társuló alkoholizmus okozta májérintettség miatt a máj glukóztermelő kapacitása is zavart szenvedett, ami szintén a súlyos hypoglykaemia kialakulásának kedvezett. A C-peptid-szint, valamint a variabilitás közötti inverz korreláció ismeretében feltételezhető, hogy az exokrin állomány károsodása a beteg esetében a béta-sejteket is elérte, csökkentve az endogén inzulinszekréciót és fokozva ezzel a vércukor instabilitását. A cardiovascularis reflextesztek igazolták a súlyos autonóm neuropathia jelenlétét, a beteg esetében az összesített autonóm score 8 volt, amely megközelíti a legsúlyosabb autonóm neuropathiát jelző 10 -es értéket. Az egyes reflextesztek mind a paraszimpatikus, mind a szimpatikus funkció romlását tükrözték, mivel mind az öt teszt kóros értékű volt. Ennek egyik magyarázata a diabetes és a rendszeres alkoholfogyasztás idegrendszert károsító, egymást erősítő hatása lehet. Irodalmi adatok szerint az autonóm neuropathia és a külső segítséget igénylő, súlyos hypoglykaemiák kapcsolatának értékelése során egyetlen autonóm paraméter kóros volta nem vezet a súlyos hypoglykaemiák számának emelkedéséhez, de két teszt kórossága esetén a súlyos hypoglykaemiák előfordulásának a kockázata 1,7-szeresre emelkedik. ${ }^{24} \mathrm{Az}$ eset érdekessége, hogy a perifériás szenzoros funkció a felső és az alsó végtagokon nem mutatkozott kórosnak. Irodalmi adatok megerősítik, hogy egyes esetekben a különböző neuronrendszerek neuropathiás érintettsége - a közös etiológiai tényezők érvényesülése ellenére - nem mutat feltétlenül párhuzamosságot. ${ }^{25}$ Súlyos autonóm neuropathia esetén a gyomorürülés lassulása ismert, ami kifejezettebb a paraszimpatikus károsodás fennállásakor. ${ }^{26} \mathrm{Be}$ tegünk esetében az izotóppal jelzett tesztreggeli gyomorból történő kiürülése extrém hosszúnak bizonyult, mintegy 7-szer hosszabb volt az anyagcsere-egészséges kontrollcsoporténál. A betegnek semmilyen emésztőszervi panasza sem volt az extrém lassú gyomorürülés ellenére sem, ami arra utal, hogy halmozottan hypoglykaemiás betegben panaszmentesen is igazolhatunk lassult gyomorürülést. ${ }^{27}$ A szövetiglukóz-monitorozás a felvételt követően egyértelművé tette a naponta ismétlődő, konzekvens reggeli és esti postprandialis hpyoglykaemia-hajlamot, amely reggeli után volt kifejezettebb. A beteg konvulzív rosszullétei is általában koradélelőtt voltak felvétele előtt. A reggeli hypoglykaemiákat késő délelőtti-déli hyperglykaemia követte a Somogyi-jelenség részeként. A beteg felvételekor reggel, délben és este evés előtt gyors hatású humán inzulint és lefekvés előtt intermedier NPH-inzulint adagolt. A reggeli és esti gyors hatású inzulinok beadása után a reggelik és vacsorák maradéktalan elfogyasztása ellenére is hypoglykaemia lépett fel a gastroparesis miatt késve bekövetkező glukózfelszívódás miatt. A felszívódási viszonyokat tovább rontotta az anamnézis 
és a pancreas morfológiai képe által igazolt kezeletlen krónikus pancreatitis miatti maldigeszció. A beteg együttműködése betegségét illetően felvétele előtt alacsony volt, évekig nem járt ellenőrzésre, a pancreasenzim-szubsztitúciót nem alkalmazta, ami az ismétlődő hypoglykaemiák miatti kognitív diszfunkció részjelensége is lehetett. Terápiaváltoztatása során a gyors hatású inzulin dózisait csökkentettük, s emellett napi kétszeri bázishatású inzulinanalógot vezettünk be, melyek adagját fokozatosan feltitráltuk. A több bázis-, kevesebb bólushatás a lassú vércukor-emelkedéseket eredményesen befolyásolta, míg a hypoglykaemiákat megelőzte. Pancreasenzim-szubsztitúció bevezetésével a vékonybélben történő egyenletes szénhidrátbontást és felszívódást biztosítottuk. Diétaként a rost- és balasztmentesség figyelembevétele mellett napi egyenletes elosztású, kis mennyiségű étkezést javasoltunk, ez gyomorürülési zavar esetén előnyös hatású. A neuropathia oki kezelésére törekedve az antioxidáns hatású és az autonóm neuropathia esetén is igazolt effektivitású ${ }^{28}$ alfa-liponsav parenterális majd per os adására került sor. Parenterálisan majd per os napi $3 \times 10 \mathrm{mg}$ metoclopramidot adagoltunk, mely rövid távon fokozza a gyomor kontraktilitását, javítja a pylorus relaxációját és hányingerellenes hatású. A fenti terápiák mellett súlyos hypoglykaemia 6 hónap alatt egyszer sem fordult elő, $\mathrm{s}$ a féléves kontroll idejére a gyomorürülés lassultsága a felére csökkent. A kontroll-CGM-görbe szerint a beteg napi cukorprofiljai messze vannak a normoglykaemiától, de a konzekvens hypoglykaemia-hajlam megszűnt, és a beteg diabetesét jellemző paramétereket, valamint a személyes körülményeit figyelembe véve az elért anyagcsereállapot-változás eredményesnek tekinthető. A beteg többször hangsúlyozta életminőségének jelentős javulását. Összefoglalásul megállapíthatjuk, hogy a visszatérő konvulzív rosszullétek és eszméletvesztések hátterében diabeteses betegekben súlyos hypoglykaemia is állhat, akár a klasszikus beharangozó tünetek hiánya esetén is. $\mathrm{Az}$ autonóm reflexteszt elvégzése, a folyamatos glukózmonitorozás és a gyomorürülés vizsgálata szükséges lehet az ingadozó vércukorértékek okának felderítésére. Az anyagcserehelyzethez adaptált inzulinkezelés, a pancreasenzimek szubsztitúciója, a neuropathia oki kezelése, prokinetikum időszakos adása elősegítheti az anyagcsere stabi- lizálását és az életminőség javulását komplex okból bekövetkező glukózvariabilitás és hypoglykaemia esetén pancreatogen diabetesben. 


\section{Irodalom}

1. Bibok Gy, Hosszúfalusi N: A glikémiás variabilitás fogalma és jelentősége a mindennapi gyakorlatban. Diabetologia Hungarica 2015; 23: 101-113.

2. Saisho $\mathrm{X}$ : Importance of beta cell function for the treatment of type 2 diabetes. J Clin Med 2014; 3: 923-943. doi:10.3390/jcm3030923

3. Fukuda $M$, Tanaka $A$, Tahara $Y$, Ikegami $H$, Yamamoto $Y$, Kumahara $Y$, et al: Correlation between minimal secretory capacity of pancreatic $\beta$-cells and stability of diabetic control. Diabetes 1988; 37: 81-88. doi:10.2337/diab.37.1.81

4. Nalysnyk L, Hernandez-Medina M, Krishnarajah G: Glycaemic variability and complications in patients with diabetes mellitus: evidence from a systematic review of the literature. Diabetes Obes Metab 2010; 12: 288-298. doi:10.1111/j.1463-1326.2009.01160.x

5. Muggeo M, Zoppini G, Bonora E, Brun E, Bonadonna RC, Moghetti P, et al.: Fasting plasma glucose variability predicts 10 -year survival of type 2 diabetic patients: the Verona Diabetes Study. Diabetes Care 2000; 23: 45-50. doi:10.2337/diacare.23.1.45

6. Monnier L, Mas E, Ginet C, Michel F, Villon L, Cristol JP, et al: Activation of oxidative stress by acute glucose fluctuations compared with sustained chronic hyperglycemia in patients with type 2 diabetes. JAMA 2006; 295 : 1681-1687. doi:10.1001/jama.295.14.1681

7. Kim MK, Jung HS, Kwak, SH, Cho YM, Park KS, Kim SY: 1,5-Anhydrod-glucitol could reflect hypoglycemia risk in patients with type 2 diabetes receiving insulin therapy. Endocrinol Metab 2016; 31: 284-291. doi:10.3803/EnM.2016.31.2.284

8. Budnitz DS, Lovegrove MC, Shehab N, Richards CL: Emergency hospitalizations for adverse drug events in older Americans. N Engl J Med 2011; 365: 2002-2012. doi:10.1056/NEJMsa1103053

9. Zaccardi F, Davies MJ, Dhalwani NN, Webb DR, Housley G, Shaw D, et al. Trends in hospital admissions for hypoglycaemia in England: a retrospective, observational study. Lancet Diabetes Endocrinol 2016; 4: 677-685. doi:10.1016/52213-8587(16)30091-2

10. Desouza CV, Bolli GB, Fonseca V: Hypoglycemia, diabetes, and cardiovascular events Diabetes Care 2010; 33: 1389-1394. doi:10.2337/dc09-2082

11. Lengyel Cs: A hypoglykaemia jelentősége diabetes mellitusban - fókuszban a cardiovascularis következmények. Diabetologia Hungarica 2015; 23:249-258.

12. Mehta HB, Mehta V, Goodwin IS: Association of hypoglycemia with subsequent dementia in older patients with type 2 diabetes mellitus. J Gerontol A Biol Sci Med Sci 26 October 2016. doi:10.1093/gerona/glw217

13. Spallone V, Ziegler D, Freeman R, Bernardi L, Frontoni S, Pop-Busui R, et al.: Cardiovascular autonomic neuropathy in diabetes: clinical impact, assessment, diagnosis, and management. Diabetes Metab Res Rev 2011; 27 : 639-653. doi:10.1002/dmrr.1239

14. Ferencz V, Istenes I, Jermendy Gy, Kempler P, Kerényi Zs, Körei AE, et al.: $\mathrm{Az}$ autonom neuropathia (AN) egyéb klinikai manifesztációi (in: Kempler P, Várkonyi T Iszerk/: Neuropathiák a klinikai gyakorlatban. Zafir Press, Budapest, 2012.) pp. 151-198.

15. Tesfaye N, Seaquist ER: Neuroendocrine responses to hypoglycemia. Ann NY Acad Sci 2010; 1212: 12-28. doi:10.1111/j.1749-6632.2010.05820.x

16. Kempler $P$, Amarenco $G$, Freeman R, Frontoni S, Horowitz M, Stevens $M$, et al: Management strategies for gastrointestinal, erectile, bladder, and sudomotor dysfunction in patients with diabetes Diabetes Metab Res Rev 2011; 27: 665-677. doi:10.1002/dmrr.1223

17. Horváth $\mathrm{V}$, Izbéki F, Lengyel Cs, Kempler P, Várkonyi T: Diabetic gastroparesis: Functional/morphologic background, diagnosis and treatment options. Curr Diab Rep 2014; 14: 527. doi:10.1007/s11892-014-0527-8
18. Rosztóczy A, Róka R, Várkonyi T, Lengyel Cs, Izbéki F, Lonovics J, et al:. Regional differences in the manifestation of gastrointestinal motor disorders in diabetic patients with autonomic neuropathy. Z Gastroenterol 2004; 42 : 1295-300. doi:10.1055/s-2004-813618

19. Terzin V, Várkonyi T, Szabolcs A, Lengyel Cs, Takács T, Zsóri G, et al: Prevalence of exocrine pancreatic insufficiency in type 2 diabetes mellitus with poor glycemic control. Pancreatology 2014; 14: 356-360. doi:10.1016/j.pan.2014.07.004

20. Piciucchi M, Capurso G, Archibugi L, Delle Fave MM, Capasso M, Delle Fave G: Exocrine pancreatic insufficiency in diabetic patients: prevalence, mechanisms, and treatment. Int J Endocrinol 2015; 2015: 595649. doi:10.1155/2015/595649

21. Makuc J: Management of pancreatogenic diabetes: challenges and solutions. Diabetes Metab Syndr Obes 2016; 25: 311-315. doi:10.2147/DMS0.S99701

22. DeVries JH: Glucose variability: where it is important and how to measure it. Diabetes 2013; 62: 1405-1408. doi:10.2337/db12-1610

23. Jermendy Gy, Kempler $P$, Keresztes K, Kollai M, Tislér A: Cardiovascularis autonom neuropathia klinikai képe, diagnosztikája (in: Kempler P, Várkonyi T /eds./: Neuropathiák a klinikai gyakorlatban. Zafír Press, Budapest, 2012.) pp. 69-121.

24. Stephenson JM, Kempler P, Cavallo Perin P, Fuller JH: Is autonomic neuropathy a risk factor for severe hypoglycaemia? The EURODIAB IDDM Complications Study. Diabetologia 1996; 39: 1372-1376. doi:10.1007/s001250050585

25. Dyck PJ, Albers JW, Andersen H, Arezzo JC, Biessels GJ, Bril V, et al: Diabetic polyneuropathies: update on research definition, diagnostic criteria and estimation of severity. Diabetes Metab Res Rev 2011; 27: 620-628. doi:10.1002/dmrr.1226

26. Várkonyi $T$, Lengyel $C s$, Takács $R$, Légrády $P$, Madácsy $L$, Lázár $M$, et al: Manifestations of diabetic polyneuropathy in the digestive tract and the central nervous system. Diabetologia Hungarica 2002; 10(Suppl. 2.): 44-50.

27. Kempler $P$, Várkonyi $T$, Körei $A$, Horváth V: Gastrointestinal autonomic neuropathy in diabetes: the unattended borderline between diabetology and gastroenterology. Diabetologia 2016; 59: 401-403. doi:10.1007/s00125-015-3826-y

28. Papanas $N$,ZieglerD: Efficacy of a-lipoicacid in diabeticneuropathy. Expert0pin Pharmacother 2014; 15: 2721-2731. doi:10.1517/14656566.2014.972935

Közlésre érkezett: 2016. november 30.

Közlésre elfogadva: 2017. február 16.

A szerzö levelezési címe:

\section{Dr. Nyiraty Szabolcs}

Szegedi Tudományegyetem, I. Belgyógyászati

Klinika

6720 Szeged, Korányi fasor 8-10.

E-mail: drnyiraty@gmail.com 